\title{
Die Nederlandse Geloofsbelydenis / Confessio Belgica en die Bybel in $1561^{1}$
}

\author{
ABSTRACT \\ The Belgic Confession and the Bible in 1561
}

As part of the celebration of the Confessio Belgica (450 years after it was written) this contribution focuses on the hermeneutical frame presupposed by and interpretation of the Bible in the confession. It is clear that Guido de Bres (main author of the confession) was well read and was able to formulate the confession in such a way that it resonated with the protestant communities of faith in the southern Netherlands - what initially was intended as a polemical attempt to distantiate themselves from the Anabaptists soon became accepted a confession of faith. The Confessio Belgica does not quote directly from Scripture but refers to biblical verses and phrases by means of free association. The use of Scripture in the Confessio Belgica is pre-critical because the literal sense of the Bible is paramount and it does not reflect self critically in terms of its own presuppositions - this does not imply that the confession is intellectually suspect or deficient! The question is also posed whether the Confessio Belgica can continue to be understood as a "repetition of Sacred Scripture" or must it be held accountable for the way in which it interpreted Scripture in the sixteenth century to maintain relevance in the twenty-first century?

\section{INLEIDING}

Die vraag na die samehang tussen die "Nederlandse Geloofsbelydenis" (NGB) en die Bybel kan op verskillende maniere geïnterpreteer word. In hierdie artikel val die klem op die verstaan van die Bybel ten tye van die opstel van die NGB en word dit aan die leser oorgelaat om na te dink oor watter bydrae die NGB lewer tot die eietydse nadenke oor Skrifinterpretasie en geloofsgemeenskappe se voortdurende uitdaging om toepaslike artikulerings van hulle geloofsoortuiging te genereer. ${ }^{2}$

$\mathrm{Na} 450$ jaar vorm die NGB steeds ' $\mathrm{n}$ betekenisvolle deel van die belydenisgrondslag van talle denominasies met ' $n$ Gereformeerde grondslag. ${ }^{3}$ Eietydse nadenke oor die betekenis van die

1 Die artikel is gebaseer op ' $n$ openbare lesing tydens die amptelike herdenking in die Fakulteit Teologie, Stellenbosch, van die 450 jarige bestaan van die Nederlandse Geloofsbelydenis, op 22 November 2011. Die viering was in die vorm van ' $n$ openbare simposium, waartydens prof. Dirkie Smit en prof. Robert Vosloo ook voordragte gelewer het. Die openbare voordrag is gedeeltelik aangepas in die lig van Emile Braekman en Erik de Boer (reds), Guido de Bres. Zijn leven, zijn belijden, Utrecht, Uitgeverij Kok, 2011 se herdenkingsbundel wat eers na die openbare simposium toeganklik was. Daarbenewens is voetnotas met verwysings bygevoeg ter wille van akademiese gebruik deur lesers. In die titel word daar na die "Nederlandse Geloofsbelydenis" sowel as die Confessio Belgica verwys omdat laasgenoemde veral in vakliteratuur buite Nederland en Suid-Afrika gebruik word.

2 Die vraag na die eietydse belang van die NGB word meer deur die bydrae van prof. Dirkie Smit, "Die

Teologiese Inhoud van die Confessio Belgica vandag" aangespreek.

3 In die Suid-Afrikaanse gereformeerde konteks publiseer JA Heyns in 1992, Inleiding tot die Dogmatiek 
betrokke belydenis sal baat vind by ' $\mathrm{n}$ studie oor die Bybelinterpretasie wat ten grondslag van die Nederlandse Geloofsbelydenis lê omdat dit interpreteerders in die 21ste eeu bewus maak van die hermeneutiese konteks waarbinne die NGB ontstaan het. ${ }^{4}$

Daar word eers gelet op die hermeneutiese agtergrond van die Skrifgebruik in die Geloofsbelydenis, met spesifieke klem op die invloed van Johannes Calvyn en die Franse Geloofsbelydenis (Confessio Gallicana) van 1559..$^{5}$ Daarna word ondersoek ingestel na die verwysing na die Bybel in die Belydenis - veral die bespreking van die oorsprong, gesag en duidelikheid van die Skrif in artikels 2-7. In 'n vorige studie van die Skrifgebruik in die NGB is ook nagegaan hoe die verwysing na Bybeltekste gebruik was om bepaalde aspekte van die Belydenis in Artikels 8-37 te motiveer. ${ }^{6}$

\section{HERMENEUTIESE AGTERGROND VAN DIE NEDERLANDSE GELOOFSBELYDENIS (NGB)}

Wie was die opsteller van die NGB, Guido De Bres, en watter invloede was bepalend vir sy hermeneutiek wat ten grondslag van sy Skrifgebruik lê? ${ }^{7}$ Opsommend kan daar op die volgende aspekte van sy lewensloop gelet word wat waarskynlik sy manier van Bybelinterpretasie beïnvloed het:

De Bres is waarskynlik in 1522 in die suidelike Nederlande (vandag België) in Bergen (Mons) gebore en kom voor 1547 tot bekering. Daar word gespekuleer dat De Bres aanvanklik as "glas-in-loodschilder" sy brood verdien het en dat hierdie ambag ' $n$ goeie kennis van die Bybel veronderstel het. ${ }^{8}$ Hierdie persoonlike Bybelstudie sou dan aanleiding tot sy bekering op ' $n$ volwasse ouderdom kon gegee het. ${ }^{9}$

Kort na sy bekering tot die Protestantisme vlug De Bres na Engeland uit vrees vir moontlike

aan die hand van die Nederlandse Geloofsbelydenis, Pretoria: NGKB. Prof. Heyns stel dit onomwonde in die Voorwoord dat die NGB nog steeds " $n$ "rigtinggewende belydenisgeskrif van ons kerk" is. Die vraag tot watter mate die NGB steeds dieselfde rigtinggewing in die 21ste eeu bied, word deur die ander bydraes van Proff Smit en Vosloo in hierdie uitgawe aangespreek.

4 Die opmerking probeer nie eietydse lesers van die NGB vervreem nie maar poog wel om ' $n$ historiese en teologiese bewussyn te kweek om die belydenisskrif binne die konteks van sestiende eeuse Skrifverstaan te begryp wanneer nagedink word oor hoe die NGB vir vandag relevant is.

5 SA Strauss, "Die Nederlandse Geloofsbelydenis," in FM Gaum et al (reds), Christelike Kernensiklopedie. Wellington: LuxVerbi BM, 789.

6 HL Bosman et al, Die Nederlandse Geloofsbelydenis - Ontstaan, Skrifgebruik en Gebruik. Pretoria: UNISA, 1987. Die navorsingsprojek het voortgevloei uit die behoefte om teologiese navorsing meer interdissiplinêr te bedryf en om ' $\mathrm{n}$ bydrae te lewer tot die besinning rondom belydenisskrifte in kerke wat op gereformeerde teologiese grondslag berus. Naas die bespreking van die dogmahistoriese, kerklike en politieke omstandighede waarbinne die NGB ontstaan het, is daar ook spesifieke aandag verleen aan Skrifuitleg in die sestiende eeu en 'n gepaardgaande bespreking van hoe die Ou en Nuwe Testament deur die NGB gebruik is om dogmatiese leerstellinge te verduidelik en te motiveer.

7 In die suidelike Nederlande het persoonsname dikwels ' $n$ Nederlandse en Franse vorm gehad en daarom was Guido De Bres ook as Guy de Bray bekend. GP van Itterzon, "Bres, Guido De (Guy de Bray)," in D Nauta, Biografisch Lexicon voor de Geschiedenis van het Nederlandse Protestantisme Deel 2. Kampen: JH Kok, 1983, 97-100. Terselfdertyd moet ook kennis geneem word dat plekname in die suidelike Nederlande dikwels 'n Nederlandse (Vlaamse) en Franse (Waalse) vorm gehad het: bv Rijsel (Lille) en Doornik (Tournai).

8 In samelewings met min geletterdheid was die gebrandskilderde glasvensters in Middeleeuse kerke en katedrale die prenteboeke wat die Bybel vir swak geletterde gemeentelede geillustreer het. Guido se vader, Jean De Bres, was ook ' $n$ glasskilder gewees en dit was nie ongewoon dat ' $n$ seun dieselfde ambag as sy vader beoefen het nie.

9 E Braekman, "De Jeugd van een Bergenaar," in Emile Braekman en Erik de Boer (reds), Guido de Bres. Zijn leven, zijn belijden, Utrecht, Uitgeverij Kok, 2011, $34-51$. 
vervolging. Vanaf 1548-1552 kry hy as deel van sy teologiese opleiding in London ook lesings in Hebreeus en Grieks wat sy studie van die Ou en Nuwe Testament verdiep. ${ }^{10}$ Hierdie opleiding geskied aan die Instituut vir Profesie waar die Waalse (Franssprekende) studente weekliks 'n Bybelboek behandel het en deur Galterus Deloenus oor die Hebreeuse teks van die Ou Testament en Johannes a Lasco oor die Griekse teks van die Nuwe Testament onderrig is. ${ }^{11}$

Na vier jaar in London keer De Bres terug na die Nederlande en vanaf 1552 tot 1556 tree hy as predikant in die suidelike Nederlande op met besondere sukses in die gemeente van Rijsel (Lille) wat voorheen deur Lutherane bearbei was. ${ }^{12}$ Dit is gedurende hierdie tydperk dat De Bres sy eerste boek in 1555, Le Baston de la Foy chrestienne ("Die stok / wapen van die Christelike geloof") publiseer waarin hy klem daarop lê dat die Bybel die enigste bron van alle wysheid is en nie die kerklike leertradisie nie. ${ }^{13}$ Hierdie boek was in reaksie op Nicole Grenier se Le bouclier de la foy ("Die skild van die geloof") wat bestaan het uit 'n apologie teen die Kerkhervormers met aanhalings vanuit die Bybel en die Vroeë Kerkvaders ter ondersteuning vir die Rooms Katolieke dogma. ${ }^{14}$

Gedurende die tydperk 1556-1558 ondergaan De Bres verdere teologiese opleiding in Duitsland (Frankfurt) asook in Switserland (vermoedelik onder andere onder Theodore Beza in Lausanne en Johannes Calvyn in Geneve). ${ }^{15}$ Sommige kerkhistorici is versigtig om ongenuanseerd ' $n$ sterk Calvinistiese invloed op De Bres te veronderstel aangesien daar weinig persoonlike kontak met Calvyn was. Hoewel daar geen gedokumenteerde bewyse daarvoor is nie, word vermoed dat De Bres klasse en preke van Calvyn bygewoon het en dat daar minstens een brief van Calvyn in sy boekery gevind is. ${ }^{16}$ De Bres was dus Calvinisties sonder om ' $n$ slaafse navolger en naprater van Johannes Calvyn te gewees het - daarvoor was hy te belese en was sy kennis van die Kerkvaders en talle ander Hervormers te omvangryk.

Die indirekte invloed van Calvyn op De Bres word gevind in die belangrike rol wat die Franse Geloofsbelydenis (1559) op die Confessio Belgica gehad het en waarvan Calvyn ook een van die opstellers was. Daar is ' $n$ ooglopende ooreekoms tussen die voorblaaie van die Confessio Gallicana en die Confessio Belgica met bykans dieselfde bewoording en aangehaalde teksgedeelte (1 Pet

10 K Exalto 1987. In het Rechte Spoor. Inleiding tot de Nederlandse Geloofsbelijdenis. Kampen: Kok, 13 beskryf hoe Engeland in die regeringstyd van Edward VI 'n toevlugsoord vir Hervormingsgesindes was en dat De Bres hom by die Franssprekende deel van die Nederlandse vlugtelingsgemeente in London aangesluit het.

11 E Braekman 2011, "Het Toevluchtsoord in London," in Emile Braekman en Erik de Boer (reds), Guido de Bres. Zijn leven, zijn belijden, Utrecht: Kok, $52-62$.

12 JL Oosthuizen, "Guido Des Bres," in FM Gaum et al (reds), Christelike Kernensiklopedie. Wellington: Lux VerbiBM, 209-210.

13 E Braekman 2011, "Predikantswerk in Rijsel," in Emile Braekman en Erik de Boer (reds), Guido de Bres. Zijn leven, zijn belijden, Utrecht, Uitgeverij Kok, 75-89 wys ook uit dat Des Bres se eerste publikasie aan die gemeente van Rijsel opgedra was.

14 Exalto, In het Rechte Spoor, 17 dui aan dat Des Bres se eerste publikasie juis probeer het om met behulp van aanhalings vanuit die kerkvaders soos Augustinus en die Bybel die Roomse aantygings teen die Protestantisme te weerlê.

15 Begrippe soos "Duitsland" en "Switserland" word hier ietwat anachronisties gebruik omdat die Europese geopolitieke konteks van die sestiende eeu in talle opsigte beduidend van die 21 ste eeu verskil.

16 NH Gootjes 2007, The Belgic Confession. Its History and Sources. Grand Rapids: Baker Academic, 62 omskryf versigtig die moontlike invloed van Calvyn op De Bres: "Guido de Bres read at least one book written by Calvin, owned at least one book by him, and exchanged at least one letter with him. He may have met him in Strassbourg, and more likely in Geneva. But classifying de Bres exclusively as a student of Calvin does not reflect the actual situation. He was in contact with more Reformed theologians, and he owned books written by a variety of theologians including some outside of the strictly Calvinistic tradition." 
3:15). Rohls is van mening dat die Franse Geloofsbelydenis "intensifies Biblicism in the sense of a formal scriptural principle" en in dieselfde verband verwys hy na die NGB as " $n$ belydenis waarin "the biblicistic scriptural principle took an even more intensified form." ${ }^{17}$ Die Franse Belydenis verwys na ' $n$ dubbele openbaring (Skepping en Skrif), terwyl die NGB verwys na 'n dubbele kennis van God deur sy werke (skepping) en woorde (Skrif). Volgens die Franse Geloofsbelydenis word die spesiale of besondere openbaring onderskei van die algemene openbaring na aanleiding van meer helderheid oor wat openbaar word. In die NGB word die besondere openbaring in die Skrif nie net as helderder as die algemene openbaring beskou nie, maar ook as ' $\mathrm{n}$ voller of meer omvattende openbaring. ${ }^{18}$. Hoewel die Confessio Gallica na die Apokriewe boeke as "nuttig" verwys, lys die Confessio Belgica hierdie boeke en laat dit die Kerk toe om te gebruik in soverre dit in ooreenstemming met die Kanonieke boeke is. ${ }^{19}$

Tydens die nag van 1 en 2 November 1561 word 'n pakkie oor die vestingmuur van die kasteel van Doornik (Tournai) gegooi. Die inhoud van die pakkie was ' $n$ brief aan die owerheid (kommissarisse van die landvoogdes) en 'n geloofsbelydenis wat in die opskrif aanspraak gemaak het dat dit met die instemming van Nederlandse gelowiges gemaak word. ${ }^{20}$ Die aanvanklike bedoeling van die opstelling van die NGB in 1561 was dat dit in samehang met die begeleidende brief ' $n$ verontskuldiging teenoor die Spaanse besetters van die Nederlande behels het dat die Calviniste nie met die onstuimige Wederdopers verwar moet word nie. Gou het die helder formulering van die belydenis aanklank by die Nederlandse Protestante gehad en is dit by daaropvolgende sinodes met geringe wysigings aanvaar.

Dit is moeilik om met enige mate van noukeurigheid De Bres se teologiese verwysingsraamwerk te rekonstrueer in terme waarvan die NGB opgestel is. ${ }^{21}$ Die kerklike kommissarisse wat na die bekendmaking van die NGB ondersoek na De Bres ingestel het, ontdek in Januarie 1562 De Bres se biblioteek met die boeke wat hy na alle waarskynlikheid tydens die formulering van die NGB benut het. Sommige van die belangrikste skrywers van wie boeke in die De Bres versameling gevind is, is: Bucer, Bullinger, Calvyn, Luther, Melanchton, Oecolampadius en Zwingli..22 Watter hervormer het die sterkste invloed op de Bres en die NGB uitgeoefen? Sybrand Strauss het onlangs die Calvinistiese invloed opnuut beklemtoon omdat hy duidelike ooreenkomste tussen die NGB se struktuur en teologiese argumentasie en die Institusie van Calvyn bespeur: (a) die Trinitariese indeling aan die hand van die werk van die Vader, Seun en Heilige Gees; (b) die sogenaamde openbaringshistoriese ontplooing binne die Bybel vanaf die skepping en sondeval in Genesis, deur die verlossing in die Evangelies tot die laaste oordeel in Openbaring. ${ }^{23}$

17 J Rohls 1998. Reformed Confessions. Theology from Zurich to Barmen (Columbia Series in Reformed Theology). Louisville: Westminster John Knox, 17.

18 Rohls, Reformed Confessions, 32 tref ' $n$ belangrike onderskeid tussen die Franse Geloofsbelydenis en die NGB se Skrifbeskouing: "For the French Confession, special revelation is distinguished from general revelation solely by the former's greater degree of clarity (clairment)... By contrast, the Belgic Confession characterizes the special knowledge of God not only as clearer (plus manifestement), but also as fuller (pleinement)...

19 Meer aandag vir die Skrifgebruik van die NGB word in die derde deel van die artikel gevind.

20 L Doekes 1975. Credo. Handboek voor de Gereformeerde Symboliek. Amsterdam: Ton Bolland, 55 is versigtig om nie te aanvaar dat De Bres self die pakkie oor die kasteelmuur gegooi het nie ("heeft de Bres een exemplar van de belijdenis met een begeleidend schrijven over die buitemuur van het kasteel in Doornik geworpen of laten werpen").

21 Dit is buitendien nie altyd duidelik watter dele van die NGB deur De Bres geskryf is en watter dele of sinsnedes die resultaat van latere sinodale redaksies is nie.

22 Gootjes, Belgic Confession, 18-19: "The library also contained papers with notes in French and Latin.

The committee noted that the handwriting was familiar to that of the letter thrown into the castle... This provided convincing proof that the letter had been written by Guido de Bres."

23 SA Strauss 2008. "Die Nederlandse Geloofsbelydenis," in FM Gaum et al (reds), Christelike 
In 1565 verskyn De Bres se omvattendste publikasie, La racine, source et fondement des Anabaptistes ("Die wortel, oorsprong en grondslag van die Wederdopers"), waarin veral die Hervorming se verbondsleer verduidelik word. Hierdie laaste boek van de Bres beslaan 920 bladsye en is opgedra "Aan de Kerk van onze Heere Jezus Christus, die verstrooid is in de lage landen."24

Tydens ' $n$ sinode in Antwerpen (1566) word die NGB met enkele veranderings aan die teksverwysings as belydenis aanvaar. Hierna is die NGB in Duits en Latyn vertaal en eers in 1581 gelas die Sinode van Middelburg dat ' $n$ Nederlandse vertaling van die Confessio Belgica gemaak word. ${ }^{25}$

$\mathrm{Na}$ ' $\mathrm{n}$ kort verblyf in Antwerpen verskuif De Bres later in 1566 na Valenciennes waar hy ' $\mathrm{n}$ effektiewe bediening in samewerking met Peregrin de la Grange van stapel stuur. ${ }^{26} \mathrm{Na}$ ' $n$ beleg van enkele maande word Valenciennes deur die Spanjaarde verower en de Bres word in die gevangenis geplaas terwyl die aanklagte teen hom ondersoek is. Guido de Bres word in 1567 deur die Inkwisisie skuldig bevind en op 31 Mei in die openbaar voor 'n groot skare aan ' $n$ galg opgehang. ${ }^{27}$

Samevattend: Die NGB was vanuit die staanspoor as ' $n$ Calvinistiese belydenis bestempel en daarom het selfs die kerklike kommissarisse, wat aan die einde van 1561 moes ondersoek instel na die naamlose NGB, bevind dat dit "vol van die soort foute en perverse leerstellinge van Calvyn" is. ${ }^{28}$ Die keuse om die NGB primêr binne " $n$ Calvinistiese verwysingsraamwerk te verstaan is tiperend van talle bestaande verklarings van die NGB wat dit teen die agtergrond van Calvyn se teologie probeer verduidelik. ${ }^{29}$ In die hieropvolgende bespreking van die Skrifgebruik van die NGB sal gepoog word om te midde van die onmiskenbare sterk invloed van Calvyn ook aan te dui dat die NGB meer as net ' $n$ blote herhaling van die ietwat ouer Franse Belydenis was en dat dit as die produk van 'n belese teoloog, Guido de Bres, verstaan moet word.

\section{SKRIFGEBRUIK IN DIE NEDERLANDSE GELOOFSBELYDENIS (NGB)}

Op die voorblad van die 1561 uitgawe van die NGB staan daar die volgende (vertaal uit Frans):

Kernensiklopedie. Wellington: Lux Verbi BM, 789.

24 E Braekman 2011, "Wortel, Oorsprong en fundament van de Wederdopers," in Emile Braekman en Erik de Boer (reds), Guido de Bres. Zijn leven, zijn belijden, Utrecht, Uitgeverij Kok, 199 - 207. Dit is belangrik om op te let dat "Wederdopers" as 'n versamelnaam gebruik word vir "alle 'protestanten' die niet behoorden tot een geïnstitueerde kerk..." (p. 200).

25 PJS De Klerk 1954. Gereformeerde Simboliek. Pretoria: Van Schaik, 49 bied 'n verhelderende opsomming van hoe die Sinode van Veere op " $n$ Franse en Nederlandse weergawe naas mekaar besluit het en dat "hierdie edisie op die Dordse Sinode gebruik is" - in weerwil van die druk van die Remonstrante.

26 Doekes, Credo, 56-57.

27 E Braekman 2011, "Laaste bediening in Valenciennes," in Emile Braekman en Erik de Boer (reds), Guido de Bres. Zijn leven, zijn belijden, Utrecht, Uitgeverij Kok, 249 - 289; E Braekman 2011, "Het 'gelukkige' einde van een martelaar," in Emile Braekman en Erik de Boer (reds), Guido de Bres. Zijn leven, zijn belijden, Utrecht, Uitgeverij Kok, 310 - 329. Meer inligting oor die martelaarsdood van de Bres kan gevind word in Jean Crespin, Histoire des martyrs, 1570.

28 Gootjes, Belgic Confession, 59: "When the commissioners in Doornik found a copy, they reported that it was "full of all kind of errors and perverse doctrine of Calvin."

29 'n Sterk samehang tussen die NGB en Calvyn word oa deur die volgende twee skrywers veronderstel:

ADR Polman 1948-53. Onze Nederlandse Geloofsbelydenis Volumes I-IV. Franeker: Wever; C Vonk 1955-56, De voorzeide leer: De Nederlandse Geloofsbelydenis I en II. Barendrecht: Drukkerij Barendrecht. 
gemaak met die gemeenskaplike ooreenkoms van

gelowiges in die Nederlande, wie begerig was om

te leef ooreenkomstig die suiwerheid van die

evangelie van ons Here Jesus Christus.

Daarop volg ' $n$ drukkersmerk met die aanhaling van 1 Petrus 3:15 (“Wees altyd gereed om 'n antwoord te gee aan elkeen wat van julle ' $n$ verduideliking vra oor die hoop in julle lewe"), maar met geen aanduiding van wie die drukker was nie. Op die drukkersmerk word daar 'n ouerige manspersoon afgebeeld wat tussen ruïnes onder wolke staan waarop die Godsnaam Jahweh in Hebreeus geskryf staan. Rondom die drukkersmerk staan daar in Latyn geskryf "Alle dinge word oud maar die Here bly altyd dieselfde". ${ }^{30}$

Volgens Gootjes word dieselfde drukkersmerk op twee ander publikasies in 1561 gevind: die eerste publikasie behels ' $n$ Franse Psalter van Clemence Marot en Theodore Beza asook die Franse Belydenis (1559); die tweede publikasie bestaan uit die vierde uitgawe van Beza se belydenis. ${ }^{31}$

In die NGB se 37 artikels word daar in die eerste elf artikels gefokus op die Triniteit en op die Bybel as een van die middele (naas die Skepping) waardeur die Drie-Eenheid geken kan word. Kortliks verwys die NGB soos volg na verskillende aspekte van die Skrif:

- Artikel 2: Die middele waardeur ons God ken - "Tweedens maak Hy Hom deur sy heilige en Goddelike Woord nog duideliker en meer volkome aan ons bekend en wel soveel as wat vir ons in hierdie lewe tot sy eer nodig is en tot die saligheid van hulle wat aan Hom behoort."32

Volgens Scheffler word Romeine 1:20 aangehaal om die openbaring van God in die natuur te beklemtoon. ${ }^{33}$ In teenstelling met die hooftema in 1:18-23 wat fokus op die toorn van God wat geen mens kan ontkom nie, gaan dit in Artikel 2 om die openbaringsmiddele. Wat Paulus as ' $n$ ondersteunende argument gebruik ('n mens kan vanuit die natuur aflei dat God daar is) word die hoofargument by die NGB. Die begrip "woord" is van besondere belang vir die NGB aangesien selfs die natuur as 'n "boek" beskou word waarin God geopenbaar kan word.

- Artikel 3: Die geskrewe Woord van God - "Ons bely dat hierdie Woord van God nie deur die wil van ' $n$ mens gestuur of voortgebring is nie, maar die heilige mense van God het dit, deur die Heilige Gees gedrywe, gespreek, soos die heilige Petrus sê (2 Pet 1:21). Daarna

30 JN Bakhuizen van den Brink 1976. De Nederlandse Belijdenisgeschriften. In authentieke teksten met inleiding en tekstvergelijkeningen Tweede Druk. Amsterdam: Ton Bolland, $\mathrm{p}$ VIII

31 Gootjes, Belgic Confession, 20. Bakhuizen van den Brink, De Nederlandse Belijdenisgeschriften, 11-12 het die drukker van die aanvanklike uitgawe van die NGB as Abel Clemence van Rouen geïdentifiseer.

32 Gootjes, Belgic Confession, 154 verduidelik hoe die Sinode van Dordt die uitdrukking "nog duideliker en meer volkome" in die lig van vrae deur die Remonstrante herformuleer het: "the Synod of Dort decided to change the formulation to "more clearly and fully" in the Dutch text. This change shows awareness of the fact that general and special revelation not only differs in clarity, but that special revelation also goes beyond general revelation."

33 EH Scheffler 1987. "Die gebruik van die Nuwe Testament in die Nederlandse Geloofsbelydenis," in HL Bosman et al, Die Nederlandse Geloofsbelydenis - Ontstaan, Skrifgebruik en Gebruik. Pretoria: UNISA, 71. 
het God deur sy besondere sorg vir ons en ons saligheid, sy dienaars, die profete en apostels, beveel om sy geopenbaarde Woord op skrif fe stel en Hy het self met sy vinger die twee tafels van die wet geskrywe. ${ }^{34}$ Daarom noem ons sulke geskrifte die heilige en Goddelike Skrif." 35

Hier word 2 Petrus 1:21 aangehaal (in samehang met die Dekaloog) om aan te toon dat die versameling van boeke (wat mettertyd in artikel 4 gespesifiseer word) die "heilige and Goddelike Skrif" is. In 2 Petrus 1:21 word daar nie na die "Woord van God" verwys nie, maar wel na "geen profesie" nie (waarskynlik verwys die teks nie na die Skrif as geheel nie, maar wel na die profetiese onderdele daarvan - vermoedelik van die Septuaginta en nie na ander dele van die Ou Testament. ${ }^{36}$

- Artikel 4: Die kanonieke boeke van die Heilige Skrif - "Ons vat die heilige Skrif in twee dele saam: die Ou en Nuwe Testament. Dit is die kanonieke boeke waarteen niks ingebring kan word nie. Hulle getal in die kerk van God is soos volg: Die boeke van die Ou Testament, naamlik die vyf boeke van Moses ... die Psalms van Dawid; drie boeke van Salomo ... die veertien briewe van die apostel Paulus ..."37

Dit is belangrik om in gedagte te hou dat die NGB 'n polemiese snykant gehad het wat na aanleiding van leerstellige verskille in die sestiende eeu verstaan moet word. Die NGB se klem op die Ou en Nuwe Testament waarteen "niks ingebring kan word nie" hou verband met die sestiende eeuse Anabaptiste of Wederdopers wat dikwels die Ou Testament gering geskat het. In teenstelling met die Rooms-Katolieke se insluiting van die apokriewe boeke by die kanonieke boeke, word die apokriewe boeke later in Artikel 6 afsonderlik gelys. Die veralgemenende verwysings na Moses as die skrywer van Pentateug, Dawid van die Psalms en Salomo van Spreuke het in SuidAfrika weerklank in die Du Plessis-saak gevind as kenmerke van gereformeerde regsinnigheid. ${ }^{38}$

- Artikel 5: Die gesag van die Heilige Skrif - “Ons aanvaar al hierdie boeke, en hulle alleen, as heilig en kanoniek om ons geloof daarna te rig, daarop te grond en daarmee te bevestig. Ons glo ook sonder twyfel alles wat daarin vervat is, nie juis omdat die kerk hulle aanvaar en as sodanig beskou nie, maar veral omdat die Heilige Gees in ons hart getuig dat hulle van God is. Hulle het ook die bewys daarvan in hulleself, aangesien selfs die blindes kan tas dat die dinge wat daarin voorspel is, plaasvind."39

34 Gootjes, The Belgic Confession, 171 stel vas dat die Franse weergawe van die belydenis die begrip "orakels" of "godsprake" gebruik, terwyl die Nederlandse / Afrikaanse uitgawe dit "geopenbaarde Woord" vertaal.

35 Gootjes, The Belgic Confession, 66 toon aan dat artikels 3 en 6, in vergelyking met die Franse Geloofsbelydenis, nuut toegevoeg is ten einde ' $n$ meer uitgebreide formulering van die leerstelling oor die Heilige Skrif te bewerkstellig - die uitbreiding dui waarskynlik op groter klem op die aard en gesag van die Bybel.

36 Scheffler, Nuwe Testament in die Nederlandse Geloofsbelydenis, 71-72.

37 Gootjes, The Belgic Confession, 68-69 maak die interessante opmerking dat die verwysing na veertien briewe van Paulus daarop dui dat die opstellers van die NGB Pauliniese outeurskap vir die Brief aan die Hebreërs veronderstel het. Dit was een van die min aspekte waar Calvyn van die NGB verskil het aangesien hy nie Pauliniese outeurskap vir die Hebreërboek aanvaar het nie - 'n aanduiding van Calvyn se goeie eksegese!

38 HL Bosman 1987. "Die gebruik van die Ou Testament in die Nederlandse Geloofsbelydenis," in HL

Bosman et al, Die Nederlandse Geloofsbelydenis - Ontstaan, Skrifgebruik en Gebruik. Pretoria: UNISA, 55.

39 Gootjes, The Belgic Confession, 122 bespreek hoe die anvanklike belydenis net twee funksies mbt die 
Hoewel daar geen uitdruklike aanhaling vanuit die Skrif gemaak word nie, word die taal van Romeine 8:16 gebruik wanneer aangevoer word dat die Heilige Gees in ons harte getuig dat die kanonieke boeke van God is. Hier spreek die NGB direk tot die wêreld van die leser nou en word daar weinig ag geslaan op historiese agtergrond of konteks van die Bybel toe. ${ }^{40}$

- Artikel 6: Onderskeid tussen die kanonieke en apokriewe boeke - “Ons onderskei hierdie heilige boeke van die apokriewe boeke: die derde en vierde boek van Esra; die boek van Tobias, Judit, die Wysheid, Jesus Sirag, Barug, die byvoegsel by die geskiedenis van Ester, die Gebed van die Drie Manne in die Vuur, die Geskiedenis van Susanna, die Beeld van Bel en van die Draak, die gebed van Manasse en die twee boeke van die Makkabeërs. Die kerk mag hierdie boeke lees en daar lering uit trek vir sover hulle met die kanonieke boeke ooreenstem ... Hulle mag nie in die minste aan die gesag van die ander, die heilige boeke, afbreuk doen nie."

Die onderskeid wat die NGB tussen die kanonieke boeke as "heilige boeke" en apokriewe boeke tref, is in reaksie op die Rooms-Katolieke tydens die Konsilie van Trent (1546) besluit om kanonieke gesag aan sommige apokriewe boeke toe te ken. Geen Nuwe-Testamentiese apokriewe word in die NGB se lys genoem nie en dit kan verklaar word teen die agtergrond van relatiewe gewildheid van die Ou-Testamentiese apokriewe en dat dit in die Bybel van die Vroeë Kerk (die Septuaginta / Griekse vertaling) opgeneem was. Hoewel die NGB nog die moontlikheid ooplaat dat die Apokriewe tydens die erediens gelees word, het die die Sinode van Dordt (161819) aanbeveel dat dit net deur lidmate gelees kan word. ${ }^{41}$

- Artikel 7: Die volkomendheid van die heilige Skrif - “Ons glo dat hierdie heilige Skrif die wil van God volkome bevat en dat alles wat die mens vir sy saligheid moet glo, daarin voldoende geleer word. Aangesien die hele wyse waarop God deur ons gedien moet word, daarin breedvoerig beskrywe is, mag ook niemand, selfs nie die apostels nie, ander leer as wat ons reeds deur die Heilige Gees geleer word nie - ja, al was dit ook ' $n$ engel uit die hemel, soos die apostel Paulus sê (Gal 1:8).42 En aangesien dit verbode is om iets by die Woord van God by te voeg of daarvan weg te laat (Deut 12:32), blyk dit duidelik dat die leer daarvan heeltemaal volmaak en in alle opsigte volkome is."

Die NGB veronderstel dat ' $n$ verbod om iets tot die Bybel by te voeg of daarvan weg te laat impliseer dat die Skrif volmaak en volkome is en dat Deuteronomium 12:32 as motivering vir so ' $\mathrm{n}$ standpunt gebruik kan word. Deuteronomium 12 behels egter ' $\mathrm{n}$ reeks voorskrifte wat verband hou met die sentrale heiligdom in Jerusalem waaraan die volk gehoorsaam moet wees en die sogenaamde kanoniese formule, "jy mag daar niks byvoeg en daar niks van weglaat nie" verwys na die voorskrifte met betrekking tot die sentrale heiligdom en nie na die Ou Testament of die Bybel as geheel nie. Die kanoniese formule stem ooreen met ' $n$ ou Nabye Oosterse

Skrif noem (om die geloof te rig en te begrond) en dat die derde funksie "om die geloof te bevestig" eers deur die hersiening in 1566 bygevoeg is. Tydens die 1566 hersiening is die slotfrase wat na "die blindes" verwys ook bygevoeg.

40 Scheffler, Nuwe Testament in die Nederlandse Geloofsbelydenis, 72-73.

41 Bosman, Ou Testament in die Nederlandse Geloofsbelydenis, 55-56. Die Apokriewe was nooit verlore nie (soos advertensies onlangs in Suid-Afrika beweer het), dit het wel binne gereformeerde kringe in onbruik verval!

42 Gootjes, The Belgic Confession, 123 het vasgestel dat die oorspronklike Franse weergawe van die NGB na "'n engel uit die paradys" verwys het (tiperend van "n vrye manier van aanhaling) en dat die 1566 hersiening dit verander het na "'n engel uit die hemel" wat meer met die aangehaalde Gal 1:8 ooreenstem. 
oortuiging dat regsbepalings onveranderlik is en dit kom in Assiriese, Babiloniese en selfs Egiptiese regskodekse voor. ${ }^{43}$ Die NGB veralgemeen dus die toepaslikheid van die kanoniese formule wat in die Ou Testament as deel van uiteenlopende vermanings gebruik word en maak dit op die volkomendheid van die Bybel as geheel van toepassing.

Galasiërs 1:8 word aangehaal en op die Skrif as geheel van toepassing gemaak. Paulus verwys egter in Galasiërs 1:8-11 na die evangelie soos deur hom verkondig en nie na die heilige Skrif as geheel nie. "Hierdie evangelie van Paulus het die 'genade van Christus' (Gal 1:6) as inhoud en nie die leer oor die volkomendheid en eksklusiwiteit van die Skrif nie". ${ }^{44}$

Dit is veelseggend dat die NGB klem daarop lê dat God die Dekaloog met sy eie vinger geskryf het en dit verleen momentum aan die siening dat God self die outeur van die kanonieke boeke was en dat die waarheid van die Bybel ten diepste in God self gesetel is. ${ }^{45}$

\section{SLOT}

Die voorafgaande bespreking van die NGB se gebruik van die Ou Testament kan aan die hand van die volgende kenmerke opgesom word: ${ }^{46}$

1. Die NGB se verwysings na die Ou Testament fokus nie op spesifieke boeke of teologiese tradisies nie (5 aanhalings vanuit Pentateug; 4 vanuit die Psalms asook 4 vanuit die Profete. Opvallend geen verwysing na wysheidstradisie nie).

2. Die NGB verwys op ' $n$ vry en fragmentariese aard na die Ou Testament. Hoewel dit gewoonlik teksgewys plaasvind was daar ten tye van die opstelling van die NGB nog nie ' $n$ finale vorm van versindeling nie en het daar nie ' $n$ tradisie bestaan waarvolgens tekste woordliks aangehaal moet word nie..

3. Die NGB maak op ' $n$ voorkritiese manier van die Ou Testament gebruik - dit beteken geensins dat die opstellers van die NGB onkrities of intellektueel minderwaardig was nie. Voorkritiese eienskappe van die NGB kan wel gevind word in die gebrek aan enige erkenning dat die NGB met Skrifaanhalings of -verwysings noodwendig die Skrif (her) interpreteer en nie bloot die "Skrifwaarhede" herhaal nie.

4. Die NGB skenk weinig aandag aan die Ou Testament se oorspronklike literêre en historiese kontekste. Dikwels word die Ou-Testamentiese aanhalings deur middel van ' $n$ proses van veralgemening binne ' $n$ vooropgestelde leerstellige oortuiging ingepas, sonder genoegsame inagneming van die aanhaling se aanvanklike literêre en historiese konteks.

5. Die NGB se verstaan van die Ou Testament word veral deur sestiende-eeuse gereformeerde teologie beïnvloed. Hierdie invloed kan gesien word in die belangrike rol wat die vroeë Kerkvaders op die Reformasie se eksegese gespeel het; die klem op die Nuwe-Testamentiese verstaan van die Ou Testament met die gepaardgaande Christologiese en tipologiese verstaan van die Ou Testament.

43 Bosman, Ou Testament en Nederlandse Geloofsbelydenis, 56-57 voer aan dat die NGB se sterk klem op die Skrif gesien moet word teen die agtergrond van die deurlopende polemiek teen die Rooms-Katolieke se waardering vir die kerklike tradisie.

44 Scheffler, Nuwe Testament in die Nederlandse Geloofsbelydenis, 73.

45 Rohls, Reformed Confessions, 37 dui op belangrike implikasies wanneer hy argumenteer: "The ante is

raised, with the thesis of the divine inspiration of scripture turning in the thesis of God's authorship."

46 Bosman, Ou Testament en Nederlandse Geloofsbelydenis, 66-67. 
Daar kan ook in breë trekke na die NGB se gebruik van die Nuwe Testament gekyk word: ${ }^{47}$

6. Die NGB haal dikwels vanuit die briefliteratuur van die Nuwe Testament aan (veral die Hebreërbrief), met weinig aandag vir die Evangelies en Handelinge.

7. Skrifaanhalings bestaan uit frases en fragmente en nie uit verse of perikope in die Nuwe Testament nie. ${ }^{48}$ Die NGB se Skrifgebruik vertoon trekke van ooreenkoms met die "dicta probantia" metode van aanhaling wat mettertyd deur die Ortodoksie gebruik was.

8. Die onmiddelike leerstellig kontekste van die NGB (apologie tov Rooms-Katolieke Kerk en die Anabaptiste) is van bepalende belang vir die Skrifgebruik van die Belydenis en die aanvanklike historiese konteks van die aangehaalde Skrifgedeeltes is van mindere belang.

Die Nederlandse Geloofsbelydenis is steeds ' $n$ klassieke gereformeerde geloofsbelydenis en is veel meer as " $n$ teologiese "fossiel" waarin die oorblyfsels van eeue oue hermeneutiese voorveronderstellings behoue gebly het. ${ }^{49}$ Ten slotte wil ek die hoop uitspreek dat die herdenking van die 450ste jaar van die NGB ' $n$ bydrae sal lewer om hernude waardering vir die teologiese waarde daarvan te ontwikkel - dat die NGB inderdaad "n staf is om mee te gaan" en nie bloot "'n stok is om mee te slaan" tydens verskille van leerstellige menings nie! ${ }^{50}$

47 Scheffler, Nuwe Testament in die Nederlandse Geloofsbelydenis, 85-97.

48 Die drukker Robert Stephanus het eers in 1551 van die huidige versindeling gebruik gemaak.

49 E de Boer 2011, "Woord vooraf," in Emile Braekman en Erik de Boer (reds), Guido de Bres. Zijn leven, zijn belijden, Utrecht, Uitgeverij Kok, 7 stel dit soos volg: "In 2011 staan we er in Nederland bij stil dat het 450 jaar geleden is dat de Nederlandse belijdenis geschreven is, en tegelijk staan we dus stil bij de man die een kerntekst van het christelijk geloof schreef die na viereneenhalve eeu klassiek is te noemen."

50 Rohls, Reformed Confessions, xvi - xvii: Die leerstellige verwysingsraamwerk waarbinne die Skrif geïnterpreteer word, is veral van deurslaggewende belang. $\mathrm{Na} 450$ jaar is daar nog steeds ' $\mathrm{n}$ spanning tussen ' $n$ meer meganiese verstaan van die inspirasie van die Skrif (springlewendig in onlangse voorbeelde van biblisisme en fundamentalisme) en 'n meer dinamiese verstaan van openbaring as ' $\mathrm{n}$ interaktiewe proses waartydens die Bybel deur die geloofsgemeenskap binne die raamwerk van geloofsbelydenisse (soos die NGB) geïnterpreteer word. 